\title{
COMPARISON STUDY OF ONLINE EDUCATION PLATFORM
}

\author{
Dr. Atul patel \\ Dr. Yogesh Parekh
}

\begin{abstract}
With a boom in increased usage of internet, online learning has also witnessed a tremendous growth in this era. Although the teaching pedagogy will vary from platform to platform, the students and society at large have benefitted from vast content in various formats, and they have experienced best learning through e-learning. Various forms of electronic media support this e-teaching and learning process. In this process, educational content is delivered over the web in the form of text, video, audio format and fulfills the need of an instructor or trainer. This paper analyses the teaching pedagogy, content and various other aspects of e-learning platforms like SWAYAM, eDX and CourseEra.
\end{abstract}

\section{Keywords: E-learning, SWAYAM, eDX, CourseEra}

\section{Introduction:}

The idea of e-Learning has fundamentally gotten investigate considerations as one development changing the examples of instructing over the globe on the side of, or somewhat supplanting the conventional up close and personal way to deal with the conveyance of information and aptitudes. The fast development in the e-content improvement utilizing web innovation and its consistently expanding utilization has given phenomenal chances to instructors to stretch out instructing material to understudies not just inside the four-dividers of their homerooms yet in addition in the solaces of their home everywhere throughout the globe. Indian Government has taken various activities, and granted various e-content advancement extends under NME-ICT for the development and improvement of - content condition. The focused on clients are not completely profiting the chance of such activities. The greater test is to get the consideration of target clients or in other words, to spread the mindfulness among its objective clients with the goal that the online students not just get the most extreme advantages from the tasks yet in addition partake in its creation and development through intuitive Learning Management System (LMS) stages. With utilization of ICT in training and setting up of National Mission in Education through ICT (NMEICT) in 2009, e-content has become the most famous learning technique that causes a student to learn at his own place. Right now we have characterized e-content and learned about the significant activities taken by Government of India for e-content and self-instruction.

Dominant part of appropriation examines center around understudy reviews, consequently there is additionally a shortage of studies that catch the educator/coach/teacher point of view with respect to execution, conveyance, and content, instructional method issues for e-content. It is indispensable to contemplate coach point of view and necessities on cloud based e- 
content administration frameworks. This exploration assessed the key noteworthy components required for college resources to utilize e-content stages. To build up an e-Learning framework that matches well with the students' needs, it is indispensable to examine teaching point of view and necessities.

\section{Analysis of various E-learning Platforms:}

\section{SWAYAM}

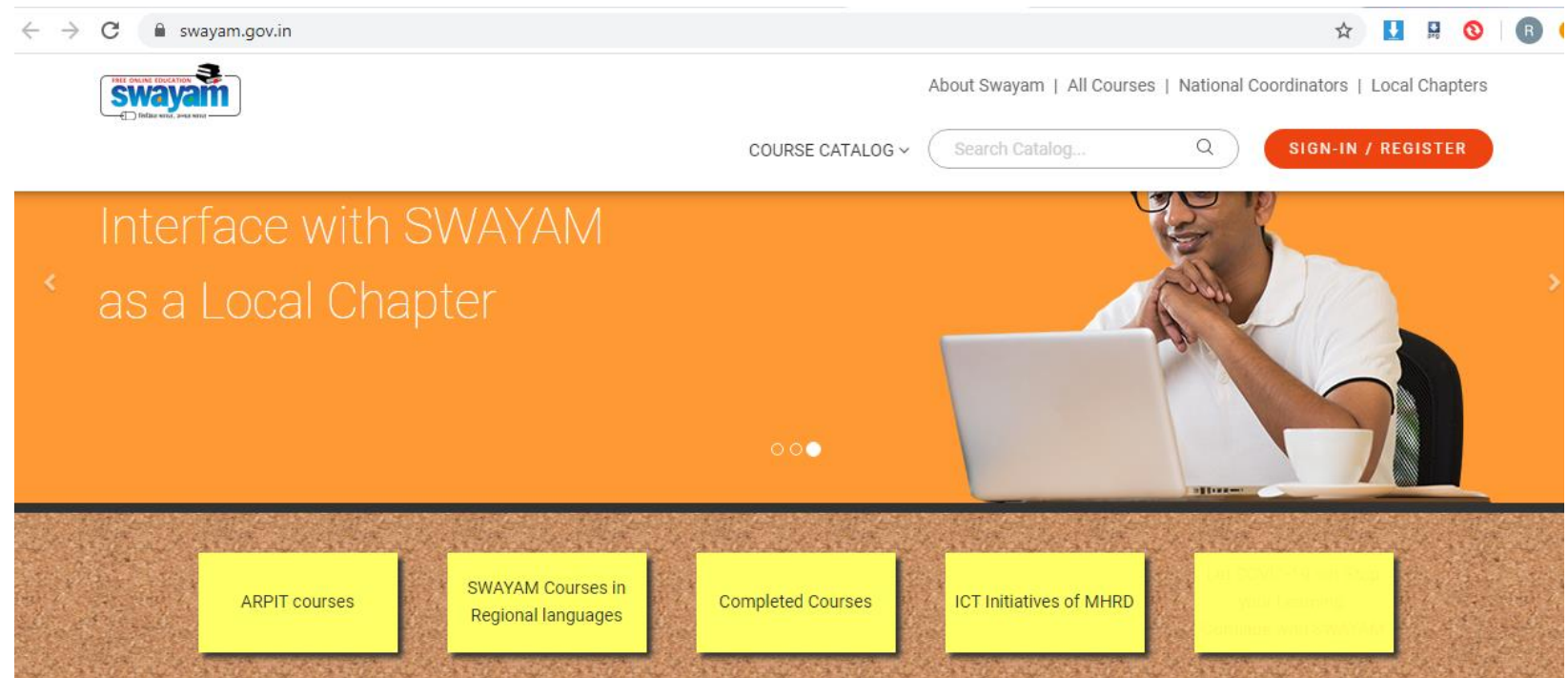

This is the home page of SWAYAM. The user who wishes to pursue any course needs to click on the tabs highlighted in yellow background color. The tab will then redirect to another page on a different tab.

\section{UDEMY}

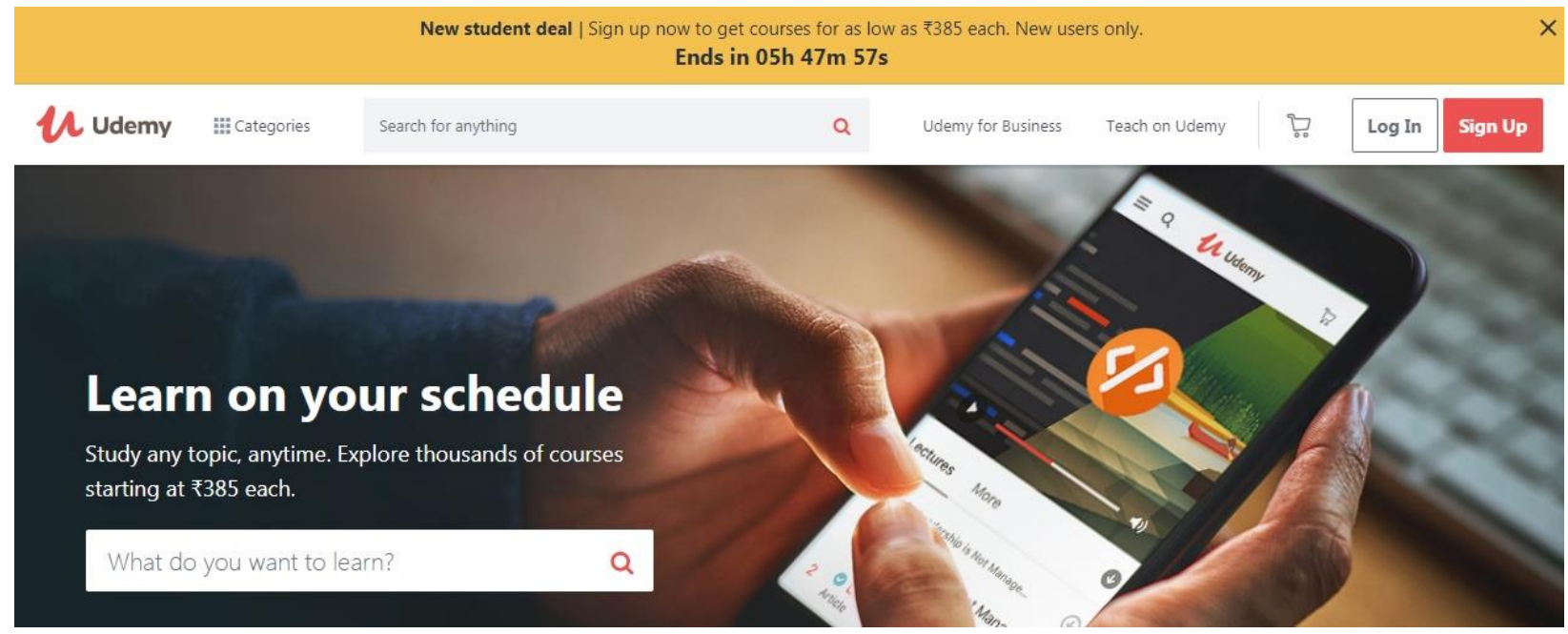


Towards Excellence: An Indexed, Refereed \& Peer Reviewed Journal of Higher Education / Dr. Atul Patel \& Dr. Yogesh Parekh/ Page 63-70

This is the home page of Udemy. On the home page, we can see search button to look for any course. By clicking on categories, we can get list of various courses.

\section{COURSERA}

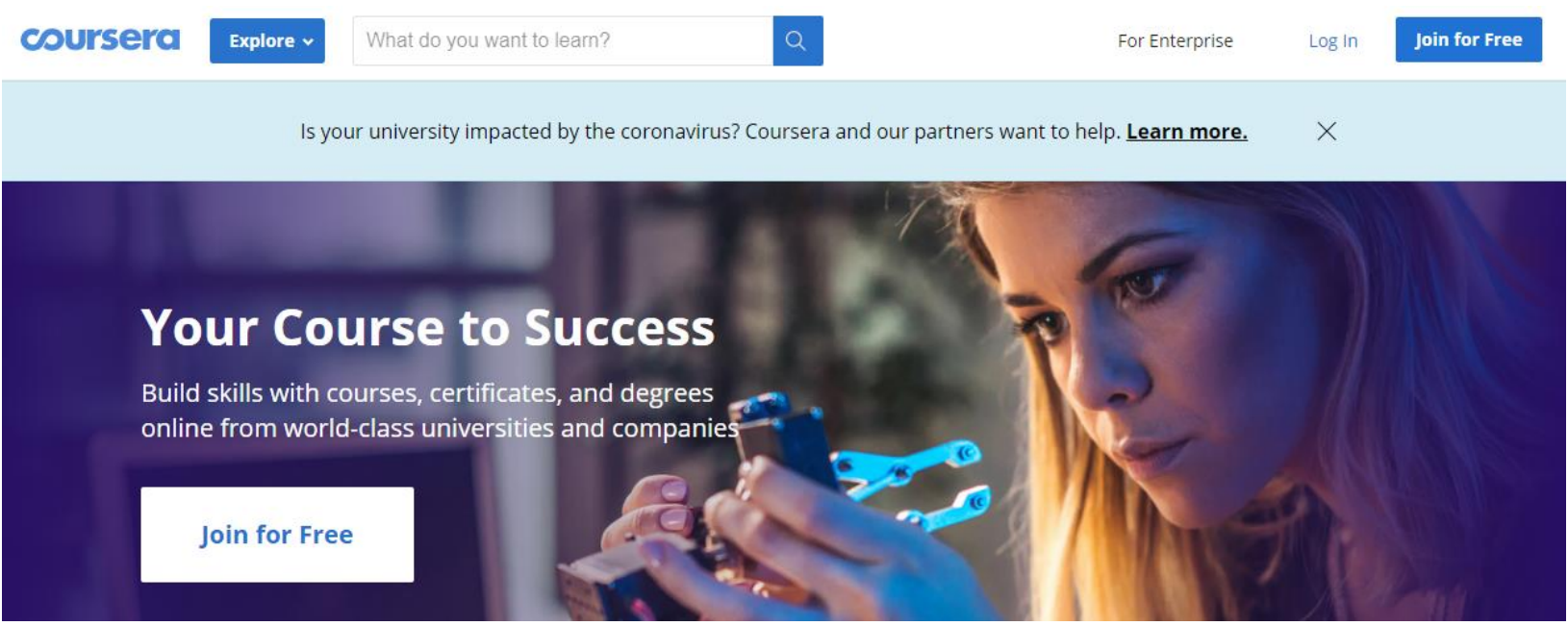

Very similar to Udemy and Swayam, Coursera also has a search box on the top of the home page

\section{SWAYAM}

\section{Swayain}
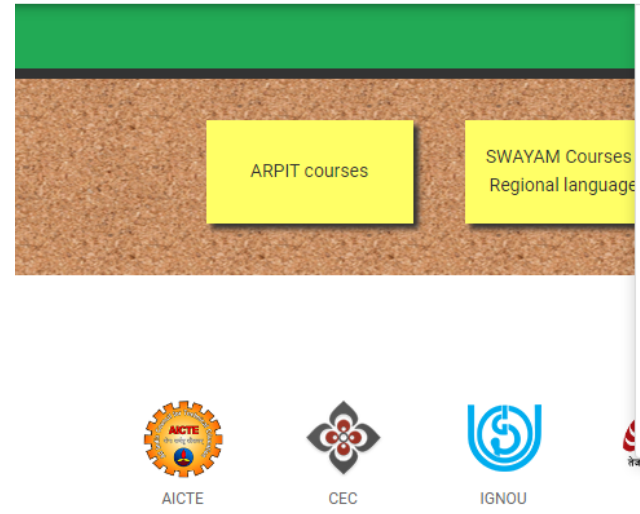

COURSE CATALOG

About Swayam | All Courses | National Coordinators | Local Chapters

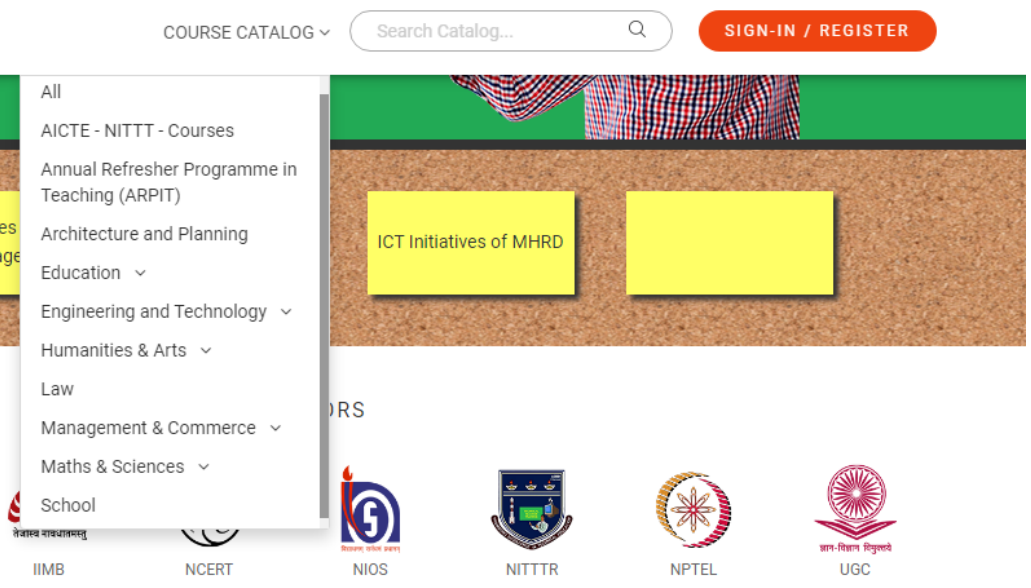

By clicking on Course catalog, course categories will open up. 
Towards Excellence: An Indexed, Refereed \& Peer Reviewed Journal of Higher Education / Dr. Atul Patel \& Dr. Yogesh Parekh/ Page 63-70

5. SWAYAM

Swayain $\odot$ NPTEL

HOME RESOURCES - COURSES BOOKS CONTACT US

\section{Course List}

$\checkmark$ - Completed

- - Ongoing

- - Yet to start

\begin{tabular}{|c|c|c|c|c|c|c|c|c|c|c|c|}
\hline S.No & Course Id & Course & Bengali & Gujarati & Hindi & Kannada & Malayalam & Marathi & Tamil & Telugu & $\begin{array}{c}\text { NPTEL } \\
\text { site } \\
\text { URL }\end{array}$ \\
\hline 1 & 106105151 & Programming in $\mathrm{C}++$ & - & - & $\checkmark$ & - & - & - & $\checkmark$ & $\checkmark$ & $\begin{array}{l}\text { Click } \\
\text { here }\end{array}$ \\
\hline 2 & 106106145 & $\begin{array}{l}\text { Programming, Data } \\
\text { Structures And Algorithms }\end{array}$ & $\checkmark$ & $\checkmark$ & $\checkmark$ & - & - & - & - & - & $\begin{array}{l}\text { Click } \\
\text { here }\end{array}$ \\
\hline
\end{tabular}

Once you click on AICTE tab, you will be redirected to another page on a different tab. The layout however is clumsy as the user needs to scroll multiple times on the page.

\section{SWAYAM}

Home >> Higher Education >> ICT Initiatives of MHRD

ICT Initiatives of MHRD (e-Brochure)

\begin{tabular}{|c|c|c|c|}
\hline S.No. & Resource & For students/Researchers & For Institutions \\
\hline \multicolumn{4}{|c|}{ Audio-Video e-content } \\
\hline 1 & $\begin{array}{l}\text { SWAYAM E: Massive Open Online } \\
\text { Courses } \\
\text { f (-) }\end{array}$ & $\begin{array}{l}\text { Earn credit through online } \\
\text { courses }\end{array}$ & $\begin{array}{l}\text { - Encourage your extraordinary faculty to } \\
\text { develop online courses } \\
\text { - Accept credits awarded under SWAYAM } \\
\text { - Form SWAYAM local chapters }\end{array}$ \\
\hline 2 & $\begin{array}{l}\text { SWAYAMPRABHAE: View digital courses } \\
\text { on TV }\end{array}$ & $\begin{array}{l}\text { Watch high quality educational } \\
\text { programs } 24 * 7\end{array}$ & $\begin{array}{l}\text { Provide facility for viewing SWAYAMPRABHA } \\
\text { content }\end{array}$ \\
\hline \multicolumn{4}{|c|}{ h SWAYAM } \\
\hline \multicolumn{4}{|c|}{ Digital content: access journals and e-books } \\
\hline 1 & $\begin{array}{l}\text { National Digital Library: e-content } \\
\text { f (우 } 90 \text { in }\end{array}$ & $\begin{array}{l}\text { Access e-content on multiple } \\
\text { disciplines }\end{array}$ & $\begin{array}{l}\text { - Get your E-content listed } \\
\text { - Form NDL Club }\end{array}$ \\
\hline 2 & e-PG Pathshala:ㅏ: Gateway for e-books & Get free books and curriculum- & Host e-books \\
\hline
\end{tabular}

\section{Technology Enabled Learning}

- Overview

- National Mission in Education through ICT

- ICT Initiatives of MHRD

- Letters/Correspondence

- Latest Updates

- swaYam Local Chapters

- List of Universities approved credit transfer

- List of Central University having Studios

The higher side of SWAYAM is that it being a government based online learning platform, makes its users updated about the initiatives made in this area. 
Towards Excellence: An Indexed, Refereed \& Peer Reviewed Journal of Higher Education / Dr. Atul Patel \& Dr. Yogesh Parekh/ Page 63-70

\section{Coursera}
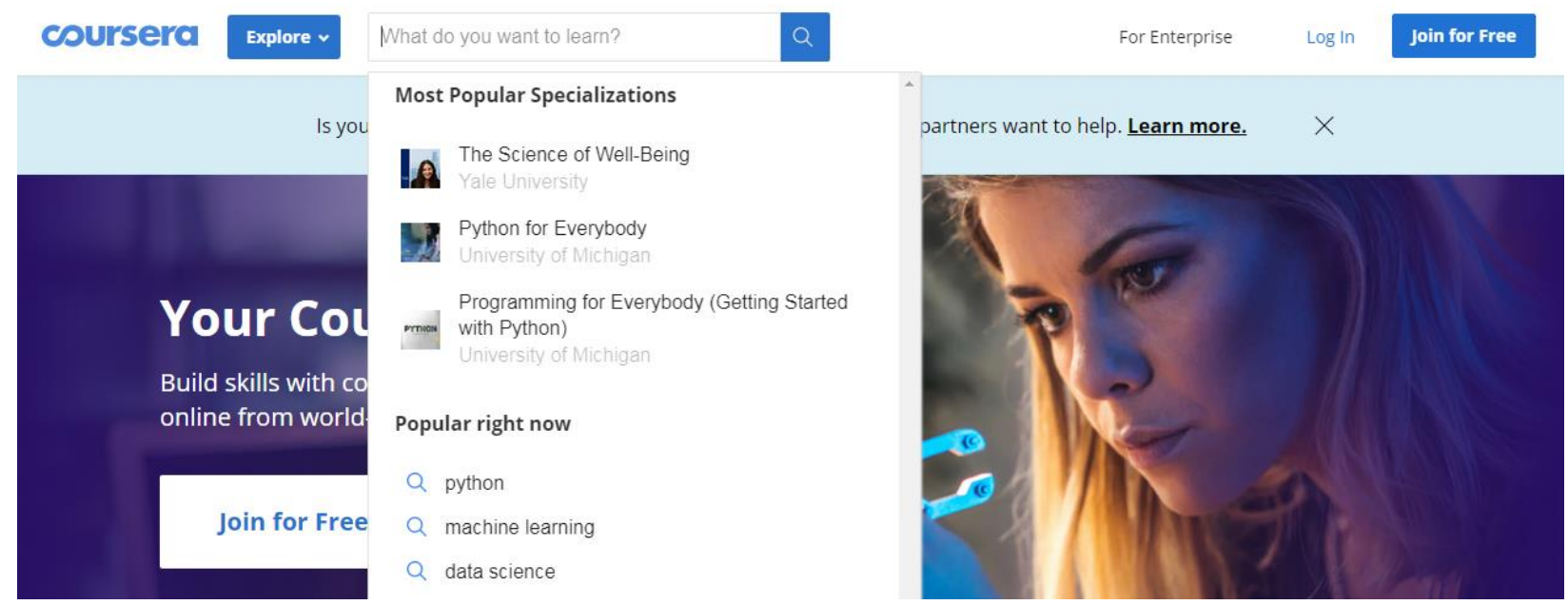

Technically Coursera is bit different from other two platforms, in a way, that by just pressing text cursor in the search box, it will display a list of all popular and most viewed courses. This makes the home page user friendly and pushes user to search for any course. This is an important feature.

\section{UDEMY}

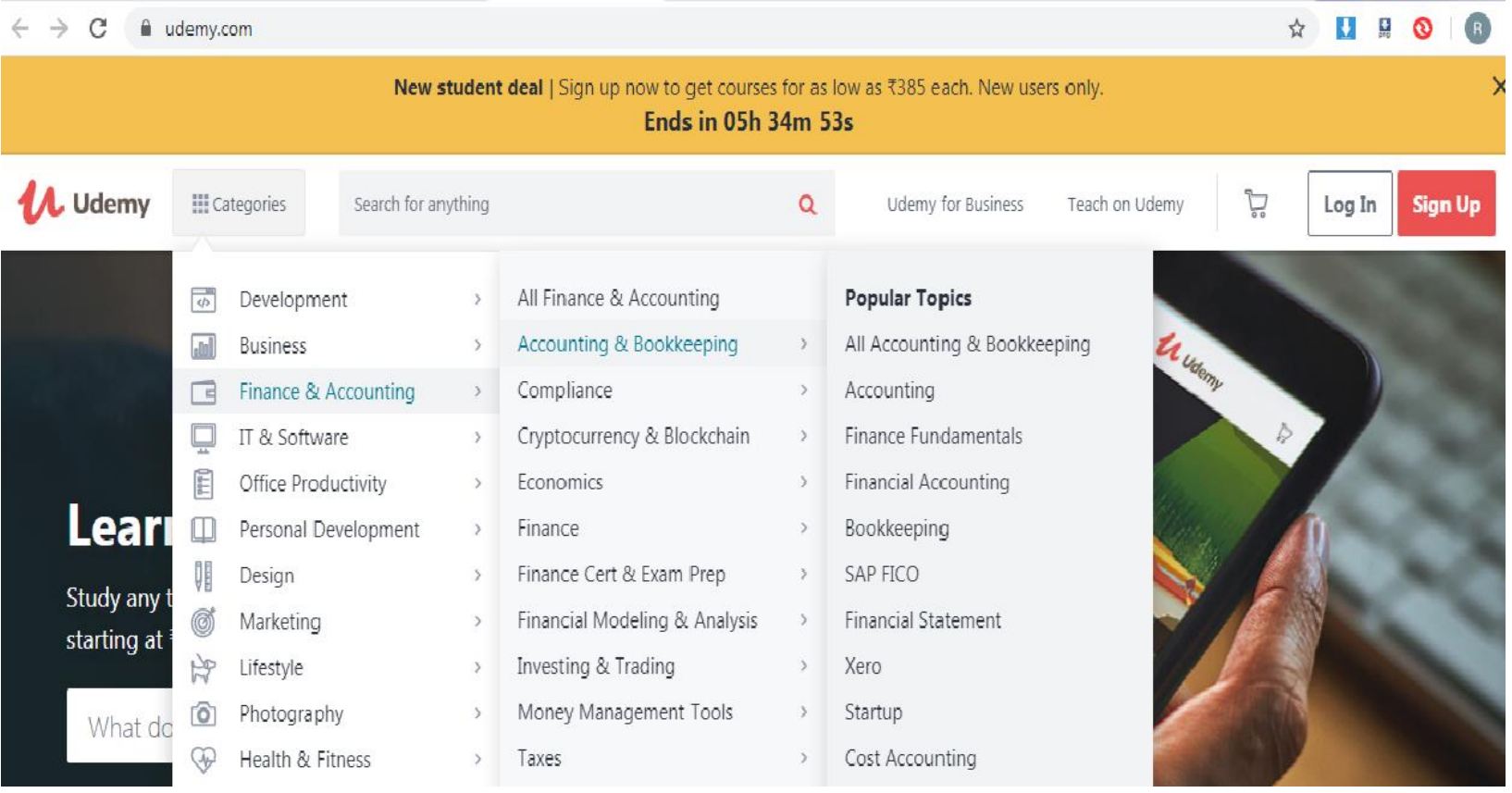

Similarly, Udemy also offers a list of courses in various categories to its users. By simply clicking on "Categories", it will display all what it has to offer you. 
Towards Excellence: An Indexed, Refereed \& Peer Reviewed Journal of Higher Education / Dr. Atul Patel \& Dr. Yogesh Parekh/ Page 63-70

\section{Comparison of Various e-Learning Platforms}

\begin{tabular}{|c|c|c|c|}
\hline Comparison Aspect & Swayam & CourseEra & Udemy \\
\hline Ownership & Government & Private & Private \\
\hline Teaching Pedagogy & $\begin{array}{l}\text { Video lectures, } \\
\text { reading material, self- } \\
\text { assessment test, } \\
\text { online discussion } \\
\text { forums for doubt }\end{array}$ & $\begin{array}{l}\text { Video lectures, } \\
\text { discussion forums, } \\
\text { homework exercise }\end{array}$ & $\begin{array}{l}\text { Video lectures, } \\
\text { Quizzes, Project }\end{array}$ \\
\hline $\begin{array}{c}\text { Types of courses } \\
\text { offered }\end{array}$ & $\begin{array}{l}\text { School education, out } \\
\text { of school education, } \\
\text { Under- graduation, } \\
\text { Post-graduation, } \\
\text { Technical education }\end{array}$ & $\begin{array}{l}\text { MOOC, } \\
\text { Specialization, } \\
\text { degree, Professional } \\
\text { certificate, Master- } \\
\text { track certificate, } \\
\text { Online degree }\end{array}$ & $\begin{array}{l}\text { MOOC, } \\
\text { Specialization, } \\
\text { Professional } \\
\text { certificate }\end{array}$ \\
\hline $\begin{array}{l}\text { Add-ons offered in } \\
\text { the course }\end{array}$ & $\begin{array}{l}\text { SWAYAM Certificate } \\
\text { (with additional fees) }\end{array}$ & $\begin{array}{l}\text { Quizzes, weekly } \\
\text { exercises, peer- } \\
\text { graded assignments }\end{array}$ & NA \\
\hline $\begin{array}{c}\text { Credit transfer in } \\
\text { course }\end{array}$ & Yes & No & Yes \\
\hline Cost & $\begin{array}{l}\text { Free, additional cost } \\
\text { for certificate }\end{array}$ & $\begin{array}{l}\text { Free, paid for } \\
\text { certificate }\end{array}$ & $\begin{array}{l}\text { Free, paid for } \\
\text { certificate }\end{array}$ \\
\hline Partners & None & $200+$ in 24 countries & $190+$ countries \\
\hline Collaboration & $\begin{array}{l}9 \text { bodies are } \\
\text { appointed }\end{array}$ & $\begin{array}{l}4 \text { universities of } \\
\text { various countries and } \\
2 \text { international } \\
\text { institutions }\end{array}$ & NA \\
\hline Certificate Type & Not Sharable & Sharable certificate & Not Sharable \\
\hline Languages Covered & NA & 30 & 65 \\
\hline Learners & NA & 53 million & 50 million \\
\hline Courses Offered & 2000 & $4570+$ & 1 lac \\
\hline
\end{tabular}


[Table 1.1]

The above table 1.1 compares three different platforms from various aspects.

As shown above, SWAYAM is an online Government led project which includes Video lectures, reading material, self-assessment test and online discussion forums for doubt as a part of teaching methodology. It includes School education, out of school education, undergraduation, Post-graduation and Technical education. If we compare SWAYAM with other two platforms like Udemy and CourseEra which are run by Private Companies, Udemy includes Video lectures, Quizzes, Project whereas CourseEra includes Video lectures, discussion forums, and homework exercise. CourseEra includes MOOC, Specialization, degree, Professional certificate, Master-track certificate, online degree but Udemy includes MOOC, Specialization, and Professional certificate. As a part of Add-ons, SWAYAM offers Certificate with additional fees, whereas Quizzes, weekly exercises, peer-graded assignments are offered by CourseEra. Udemy and SWAYAM offers the participants to transfer credit but CourseEra doesn't. The common feature of each of them is that for obtaining certificate, participate has to pay additional cost. CourseEra has the maximum number of partners among all the three$200+$ in 24 countries whereas Udemy has 190+ partners. SWAYAM lacks behind in this with no partners. SWAYAM has got collaboration with 9 bodies. With CourseEra, it has collaboration with 4 universities of various countries and 2 international institutions. Udemy lacks behind in this. Only CourseEra offers sharable certificate whereas other two don't fall in this category. Udemy offers courses in maximum number of languages i.e. 65, while CourseEra provides courses in 30 languages, whereas SWAYAM makes use of only one language i.e. English. CourseEra hold first position in context of users which is 53 million, while Udemy holds second rank with 50 million users, however, the user base of SWAYAM is not known. Udemy offers as many as 1 lac courses in varied fields, CourseEra offers $4570+$ courses while the least number of courses are provided by SWAYAM which is 2000 .

\section{CONCLUSION}

Among all the three platforms, Coursera and Udemy weigh on almost the same scale whereas SWAYAM lacks behind in various aspects as mentioned in the table 1.1. If necessary upgrades can be done for SWAYAM, it will also be reaching the standards as adopted by other two platforms. 


\section{Works Cited}

BHATT, A. (2017). A Study on Role of E-Learning in Higher Educational Institutions. IOSR Journal of Humanities and Social Science, 52-57.

PATEL, A., \& PAREKH, Y. (2018). Education Through Dth In India: Initiatives Of State \& Central Government. In Y. PATEL (Ed.), PLANNER 2018 Tripura (p. 184). TRIPURA: INFLIBNET CENTRE.

\section{Dr. Atul Patel \\ Sr. Project Associate}

\&

Dr. Yogesh Parekh

I/C. Librarian, Gujarat University Library 